\title{
INFLUENCE OF THE RESTORATION QUALITY ON THE SUCCESS OF PULPOTOMY TREATMENT: APRELIMINARY RETROSPECTIVE STUDY
}

\author{
INFLUÊNCIA DA QUALIDADE DA RESTAURAÇÃO SOBRE O SUCESSO \\ DA PULPOTOMIA: ESTUDO PRELIMINAR
}

Flávio Fernando DEMARCOํㅜ, Márcia Silva ROSA², Sandra Beatriz Chaves TARQUÍNIO³, Evandro PIVA ${ }^{4}$

\begin{abstract}
1- DDS, PhD, Associate professor, Department of Operative Dentistry, Dental School, Federal University of Pelotas, Pelotas/RS, Brazil
2- DDS, Graduate student, Federal University of Pelotas, Pelotas/RS, Brazil.

3- DDS, PhD, Associate professor, Department of Semiology and Clinic, Dental School, Federal University of Pelotas, Pelotas/RS, Brazil.

4- DDS, PhD, Associate professor, Department of Operative Dentistry, Dental School, Federal University of Pelotas, Pelotas/RS, Brazil.
\end{abstract}

Corresponding address: Professor Flávio Fernando Demarco, Department of Operative Dentistry, School of Dentistry, Federal University of Pelotas, Rua Gonçalves Chaves, 457 - Centro, Pelotas-RS, Brazil. 96015-560. Phone Number: 55-53 2723823, Fax Number: 55-53 2255581 E-mail: fdemarco@ufpel.edu.br

Received: July 12, 2004 - Modification: August 27, 2004 - Accepted: October 26, 2004

\begin{abstract}
$T$

1 he aim of this study was to evaluate the clinical status of pulpotomy treatment with calcium hydroxide and to correlate it with the quality of restoration of the treated teeth. Patients were retrieved from the files of the Operative Dentistry clinics (FOUFPel) between 1996 and 2000. Twenty-two patients were recalled, which had 23 teeth treated with pulpotomy due to exposure by caries. Seven anterior and 16 posterior teeth composed the evaluated group, being all restored with composite resin. The age varied from 15-50 years (mean 23.9) and the follow-up mean was 34.52 months. Clinical and radiographic examinations were performed to evaluate the clinical status of treatment. The criteria used, clinically favorable and failure, were based on the following clinical exams: pulp vitality; sensitivity; and periapical alterations. The quality of the restorations was based on the USPHS criteria. Pulpotomy treatment was ranked as clinically favorable in 10 teeth (43.5\%), 4 in anterior and 6 in posterior teeth. Failure was verified in 13 teeth (56.5\%), 4 anterior and 9 posterior. From the group clinically favorable, 90\% of the restorations were ranked as clinically satisfactory, while only $10 \%$ were unsatisfactory. In the failure group, $77.8 \%$ of the restorations were classified was unsatisfactory and $22.2 \%$ were ranked as satisfactory. The statistical analysis (Fisher's exact test) demonstrated that there is a statistically significant association between the clinical status of pulpotomy and restoration quality $(\mathrm{p}<0.05)$. Within the limitation of the study, it was verified that the quality of restoration could influence the favorable clinical status of pulpotomized teeth. Randomized clinical trials are required to confirm these preliminary data.

Uniterms: Calcium hydroxide; Clinical trial; Composite resin; Pulpotomy; Vital pulp therapy.
\end{abstract}

\begin{abstract}
RESUMO
$\mathrm{O}$

objetivo deste estudo foi avaliar a condição clínica de dentes submetidos à pulpotomia com hidróxido de cálcio, correlacionando com a qualidade das restaurações dos respectivos dentes. A partir dos prontuários da clínica de Odontologia Restauradora da FOUFPel, foram selecionados 22 pacientes (23 dentes) submetidos a pulpotomia entre 1996 e 2000. Ao todo, 23 dentes (7 anteriores e 16 posteriores) receberam o tratamento de pulpotomia, indicado devido à exposição por cáries, sendo que todas as restaurações foram confeccionadas com resina composta. A idade dos pacientes variou de 15-50 anos (média de 23,9 anos) e o tempo médio de acompanhamento das pulpotomias foi de 34,52 meses. Avaliações clínicas e radiográficas foram realizadas para a avaliação das pulpotomias. Ausência de hipersensibilidade, de alterações periapicais e teste de vitalidade pulpar positivo, eram as condições necessárias para que o tratamento fosse incluído no grupo "clinicamente favorável” utilizados para avaliar a condição clínica dos dentes tratados. Os critérios de avaliação clínica da USPHS foram utilizados para avaliar a qualidade das restaurações. Dez dentes (43,5\%) receberam o escore clinicamente favorável, 4 anteriores e 6 dentes posteriores. O critério falha foi atribuído a 13 dentes (56,5\%), 4 dentes anteriores e 9 posteriores. Entre os dentes do grupo clinicamente favorável, $90 \%$ das restaurações foram classificadas como clinicamente satisfatória, enquanto 10\% estavam insatisfatórias. No grupo onde houve falha, 77,8\% das restaurações foram classificadas como insatisfatória enquanto 22,2\% foram classificadas como satisfatórias. A análise estatística (Teste exato de Fisher) demonstrou que existe uma associação estatisticamente significante entre a condição clínica da pulpotomia e a qualidade da restauração $(\mathrm{p}<0,05)$. Respeitando as limitações do estudo, é possível verificar que a qualidade da restauração pode ser um fator influente para uma condição clínica favorável de dentes tratados com pulpotomia. Estudos clínicos controlados são necessários para confirmar esses achados preliminares.

Unitermos: Hidróxido de cálcio; Avaliação clínica; Resinas compostas; Pulpotomia; Terapia pulpar vital.
\end{abstract}




\section{INTRODUCTION}

Vital pulp therapy for permanent teeth with pulp exposure by caries remains one of the most controversial areas in dentistry. Because a vital, functioning pulp is capable of initiating several defense mechanisms to protect from bacterial invasion, it is beneficial to preserve the vitality and health of an exposed pulp rather than to replace it with a root end filling ${ }^{29}$.

The pulpotomy is a conservative therapy that aims at maintaining the pulp vitality, and has been considered a provisional treatment for teeth with incompletely formed roots, to be followed by traditional root therapy ${ }^{13}$. However, histological ${ }^{7,16}$ and clinical findings ${ }^{4,20}$ have demonstrated the success of pulpotomy to treat traumatized or carious teeth with inflamed pulps, despite the condition of the apex. Additionally, some studies have disclosed the resolution or regression of periapical alterations in carious teeth treated with pulpotomy ${ }^{3,28}$. Such findings have reinforced the high capacity of the pulp tissue to heal ${ }^{18}$.

Moreover, pulpotomy treatment has one relevant economic and social aspect, since in developing countries the percentage of the population who could afford an endodontic treatment is reduced. In such situations, pulpotomy is a treatment that could prevent the early loss of molar teeth. In addition, it is a less time-consuming and less-expensive treatment when compared to traditional endodontic therapy and could be performed by general clinician, while root canal treatment may require a specialist, mainly in molar teeth ${ }^{8}$.

The rationale for the pulpotomy success is based on the evidence that inflammatory response and vascular alterations are restricted to the superficial coronal pulp tissue, while the pulp tissue in the root canal remains normal. In such technique, the coronal pulp tissue is removed and the cut tissue is covered with a material that could stimulate the repair, forming the mineralized barrier ${ }^{21}$.

Calcium hydroxide products have been considered the outstanding materials for pulp capping ${ }^{27}$, stimulating the dentin barrier formation in exposed inflamed pulps ${ }^{5}$.

The quality of the final restoration is a relevant topic when considering the possibility of success in the pulp capping treatment. Cox, et al..$^{5}$ (1985) observed that unsatisfactory restorations, which allowed penetration of bacteria and their by-products, could lead to failure of the conservative pulp therapy in long-time observation. In a long-term follow-up of conservative pulp treatments made due to caries removal, Barthel, et al. ${ }^{2}$ (2000) found 37\% of success after five years and $13 \%$ after ten years. These treatments were performed by undergraduate students. The authors verified that early placement of definite restorations was a significant factor to increase the success rate. Nevertheless, despite the tendency observed at the 5-year follow-up, the quality of the restoration did not influence the percentage of pulp capping success.

The clinical evaluation of pulpotomies in long-term is essential, ${ }^{17}$ and the quality of restorations in pulpotomized teeth should be investigated as a potential factor associated to the pulp therapy success.

The hypothesis to be tested is that the quality of the restoration does not affect the success of pulpotomy treatment. Thus, the purpose of this study was to evaluate the correlation between the success of pulpotomies and the quality of the definite restoration.

\section{MATERIALS AND METHODS}

\section{Treatment procedures}

The objective and procedures to be performed in this study were approved by the Ethics Committee (Federal University of Pelotas). Also, the patients were informed on the objective of the study and provided a written consent to participate in the research.

In the Operative Dentistry Clinic (Federal University of Pelotas -Brazil), pulpotomies had been performed between 1996 and 2000. The entire sequence of procedures was performed under rubber dam isolation to prevent contamination by saliva. All treatments were made by dental students under supervision of an instructor (Faculty staff). In all cases, the pulps were exposed during caries removal. Following exposure, the roof of the pulp chamber was removed and the pulp tissue was checked to observe the conditions that indicate possibility of repair: red bleeding, tissue consistency to cutting and time of hemostasis ${ }^{11,28}$. Also, the teeth selected for pulpotomy treatment should have only pain under stimulation (to cold) and not exhibit pain to percussion or palpation. Sensitivity to cold was tested by a cotton pellet embedded in $\mathrm{CO}_{2}$ (Endo-Frost, Roeko), and the heat test was performed with low-fusing compound. Thermal tests were performed in the buccal cervical region of pulpotomized tooth. Only one professional performed the vitality diagnosis of pulp.

The pulp tissue was removed using a sharp curette ${ }^{12}$. The control of bleeding was obtained with sterile cotton pellets and calcium hydroxide solution. The wound was dressed with calcium hydroxide powder and calcium hydroxide cement covered the powder and adjacent dentin. The cavities were temporarily restored with ZOE cement. After 45 to 60 days, the provisional restoration was removed and the presence of a dentin barrier was checked. The dentin barriers were covered with calcium hydroxide cement and the cavities were restored using a sandwich technique, with a chemically cured glass ionomer cement (Vidrion, SS White), adhesive (Scothbond Multipurpose, 3M ESPE) and composite resin (Z100, 3M ESPE).

\section{Criteria for pulpotomy status evaluation}

A pulp capping was considered as clinically favorable when the tooth responded to the sensitivity test $\left(\mathrm{CO}_{2}\right.$ test and heat test) and there was absence of clinical symptomatology and radiographic signs of apical radiolucency. If the tooth was extracted or submitted to endodontic therapy, it was classified as a failure. Also, the 
presence of detectable apical rarefaction on radiographic examination or the presence of spontaneous pain or pain under percussion led to classification as failure.

\section{Classification of the restorations quality}

Restorations were classified according to the modified USPHS (United States Public Health Service) criteria, based on the clinical examination ${ }^{1}$.

In this study, restorations ranked as ideal (Alpha) or acceptable were classified as satisfactory restorations, while restorations ranked as unacceptable (USPHS criteria) were classified as unsatisfactory (Table 1 ).

\section{Follow-up examination}

In 2002, the patients were retrieved from the Operative Dentistry clinic files. They were re-called for evaluation of the pulpotomized teeth.

One operator performed the clinical examination that consisted of inspection, palpation, percussion test, and sensitivity tests (thermal tests). A radiographic examination was taken to investigate the status of the apical region and continuity of the periodontal ligament space. The quality of the restoration was assessed by the same examiner with clinical and radiographic (overhangs or gaps) evaluations.

A descriptive analysis of the pulpotomy clinical status rate was obtained, and the correlation between this clinical status and quality of restoration was studied using the Fisher's exact test at the $\mathrm{p}<0.05$ significance level.

\section{RESULTS}

Twenty-two patients with 23 pulpotomy treatments attended to recall. The patients' age (at the pulpotomy treatment), patients' gender, follow-up time, and location of the tooth are show in Table 2 . From the 16 posterior, 12 were Class II MOD (75\%), 2 Class II MO (12,5\%) and the remaining two were Class I (12,5\%). All posterior restorations were large, with at least one third of the buccal-lingual (intercuspid) distance. The composite used to perform all restorations was a micro hybrid resin (Z100, 3M ESPE) and the adhesive system was employed following the total etch technique (Scotchbond
Multipurpose, 3M ESPE), being the restorations performed under rubber dam isolation.

The information regarding clinical and radiographic evaluations is presented in Table 3. In two cases, the teeth were extracted before the evaluation and in other two cases root canal treatment was made in the pulpotomized teeth.

TABLE 2 - Sample description

\begin{tabular}{|c|c|c|}
\hline Variables & $\mathbf{n}$ & uency (\%) \\
\hline \multicolumn{3}{|l|}{ Age $^{\star}$} \\
\hline $15-30$ & 18 & 81.8 \\
\hline $31-50$ & 4 & 18.2 \\
\hline Total & 22 & 100.0 \\
\hline Mean (SD) & $23.9( \pm 9.25)$ & \\
\hline Median & 21 & \\
\hline \multicolumn{3}{|l|}{ Sex } \\
\hline Male & 10 & 43.5 \\
\hline Female & 13 & 56.5 \\
\hline Total & 23 & 100.0 \\
\hline \multicolumn{3}{|c|}{$\begin{array}{l}\text { Pulpotomized } \\
\text { teeth evaluated }\end{array}$} \\
\hline Anterior & 7 & 30.4 \\
\hline Posterior & 16 & 69.6 \\
\hline Total & 23 & 100.0 \\
\hline \multicolumn{3}{|c|}{ Follow-up (months) } \\
\hline $16-28$ & 9 & 39.1 \\
\hline $28-40$ & 2 & 8.7 \\
\hline $40-52$ & 12 & 52.2 \\
\hline Total & 23 & 100.0 \\
\hline Mean (SD) & $34.5( \pm 12.54)$ & \\
\hline
\end{tabular}

* Age at the pulpotomy treatment time

TABLE 1- USPHS criteria for composite restorations qualification

\begin{tabular}{llc}
\hline Criteria for clinical assessment & Satisfactory & Restoration quality \\
& Unsatisfactory \\
\hline Caries & Alfa & Bravo \\
Color match & Alfa \& Bravo & Charlie \\
Cavo surface marginal discoloration & Alfa \& Bravo & Charlie \\
Surface roughness & Alfa \& Bravo & Charlie \\
Marginal adaptation & Alfa \& Bravo & Charlie \\
Anatomic form & Alfa \& Bravo & Charlie \\
\hline
\end{tabular}


These patients were not clinically or radiographically examined and these cases were recorded as failure.

Ten cases (43.5\%) were classified as clinically favorable (4 anterior and 6 posterior teeth) and 13 cases (56.5\%) as failure (2 anterior and 11 posterior teeth). The follow-up average was 34.52 months. The mean age of the patients was 23.9 years and the median was 21 years.

In those cases with pulpotomy status clinically favorable, the quality of restorations was satisfactory in 9 cases (90\%) and unsatisfactory in only one case (10\%). On the other hand, the quality of restoration in the cases of failure in which the evaluation of quality was possible (9 cases), seven teeth presented unsatisfactory restorations (78\%), being satisfactory for the other 2 teeth (22\%) (Table 3).

Because of the small sample size, no correlation between the influencing factors (age, gender, follow-up time, etc) was studied. Using Fisher's exact test, a statistically significant positive association between pulpotomy status and restoration quality was found $(\mathrm{p}<0.05)$, i.e., satisfactory restoration is a significant factor for the success of pulpotomy treatment.

\section{DISCUSSION}

The hypothesis tested in the present study was rejected. Unsatisfactory restorations generally affect the clinical status of pulpotomy treatment. In the present study, 90\% of satisfactory restorations were found in those pulpotomy treatments ranked as success, while $10 \%$ were considered unsatisfactory. On the other hand, $78 \%$ of unsatisfactory restorations were observed in the pulpotomies classified as failure, while $22 \%$ were considered satisfactory. In the present study, the success obtained for pulpotomy treatment was $43.5 \%$ after 34.5 months.

The success rate of pulpotomy in clinical studies, regardless of the criteria, varies from $70 \%$ to $96 \% \%^{3,4,17,28}$. This percentage is higher than that observed in the present study. However, investigating pulp cappings performed by dental students in pulps exposed due to caries removal, Barthel et $a l^{2}$ (2000) found a success rate of $37 \%$ after 5 years and $13 \%$ in the 10-year follow-up. Some reasons could justify the differences between these findings.

First of all, dental students had performed the pulpotomy treatments in this study. The skill of the operator may be a significant aspect influencing the success of conservative treatment ${ }^{2}$. Generally, procedures performed by undergraduates would take more time to be made. Also, for every step of the treatment, they should wait for their instructor's evaluation. This could cause additional damage in an already traumatized pulp, decreasing the perspective of good prognostic ${ }^{2}$. The skill of the operator would also influence the quality of the restoration, since it has been shown that experienced (qualified) operators produced more effective and consistent results than less experienced undergraduate dental students ${ }^{26}$.

The pulpotomies in this study were made in pulps that were exposed due to caries removal. Bacterial contamination at the time of the exposure may have a negative effect on the outcome of pulp capping ${ }^{21}$. Nevertheless, pulps exposed to the oral microbiota for periods up to seven days could heal after capping with calcium hydroxide ${ }^{5}$. Pulps exposed to the oral environment resist infection, being protected by the blood clot, vascular granulation tissue and the interstitial tissue pressure of the pulp ${ }^{14}$. However, the presence of dental plaque accumulation into the carious cavity may affect the perspective of pulp recovery. Other consideration is that pulp was exposed by caries removal, but the entire coronal pulp was removed, leaving the root pulp to be protected. The evidence that inflammatory changes are restricted to the superficial coronal pulp may support the rationale for the pulpotomy success in carious teeth with inflamed pulps. The chronic response is limited to the pulp chamber, with vasodilatation and minimal inflammatory alterations in the root pulp ${ }^{13}$. Removal of the coronal pulp and dressing of the wounded surface with calcium hydroxide would provide conditions for root pulp healing with dentin barrier formation ${ }^{5}$. Several studies have demonstrated the capacity of pulp healing after pulpotomy in carious teeth, even with periapical alterations $\mathrm{s}^{3,4,28}$.

There are several changes in the pulp tissue with aging. Decrease in pulp blood supply and cell population could

TABLE 3- Relationship between quality of restorations and pulpotomy criteria

\begin{tabular}{|c|c|c|c|c|c|c|c|c|c|c|c|}
\hline \multirow{3}{*}{$\begin{array}{l}\text { PULPOTOMY } \\
\text { CRITERIA }\end{array}$} & \multirow{3}{*}{$\begin{array}{l}\text { QUALITY OF } \\
\text { RESTORATIONS }\end{array}$} & \multicolumn{10}{|c|}{ COMPLEMENTARY TEST } \\
\hline & & \multicolumn{2}{|l|}{ Pain } & \multicolumn{2}{|c|}{$\begin{array}{l}\text { Test to } \\
\text { cold }\end{array}$} & \multicolumn{2}{|c|}{$\begin{array}{l}\text { Test to } \\
\text { heat }\end{array}$} & \multicolumn{2}{|r|}{ Percursion } & \multicolumn{2}{|c|}{$\begin{array}{l}\text { Periapical } \\
\text { lesion }\end{array}$} \\
\hline & & Absent & Present & + & - & + & - & + & - & Absent & Present \\
\hline Clinically & Satisfactory $(n=9)$ & 9 & - & 5 & 4 & 4 & 5 & - & 9 & 9 & - \\
\hline favorable (10) & Unsatisfactory $(\mathrm{n}=1)$ & 1 & - & 1 & - & - & 1 & 1 & - & 1 & - \\
\hline Failure (9) & Satisfactory $(n=2$ & 1 & 1 & - & 2 & 1 & 1 & 2 & - & - & 2 \\
\hline$+\left(4^{\star}\right)$ & Unsatisfactory $(n=7)$ & 6 & 1 & - & 7 & 1 & 6 & 4 & 3 & - & 7 \\
\hline
\end{tabular}

* four teeth were categorized as "failure" due Endodontic therapy presence(2) or extraction (2). Teeth with endodontic therapy were excluded of restoration evaluation 
impair the pulp repair ability. In the present study, the mean age of the patients at the time of pulpotomy treatment was relatively young (23.9 years). However, all pulps had additional aging due to the caries process and this could reduce the capacity of repair. Eighteen patients were aged between 15 and 29 years old and four patients were aged between 30 and 50 years old. From this second group, two patients (30 and 34 years) had success in their pulpotomies treatments, while the other two (47 and 50 years) presented failures. Nevertheless, it has been highlighted that age of the patient should not be a reason to avoid the conservative treatment ${ }^{21,27}$.

There is a lack of correlation between clinical symptoms, ${ }^{21}$ and evaluation of the inflammatory status of the pulp tissue based on the responses to vitality tests and on the reported symptoms is a complex task ${ }^{11}$. The visual inspection of the pulp tissue during cutting in the pulpotomy technique remains the most important feature to be considered. Pulp tissue pink or reddish and resistant to cut, red bleeding and normal hemostatic time could indicate a pulp with healing potential ${ }^{11,28}$. The decision for pulpotomy indication in this study was based on the response to vitality tests and mainly on the clinical condition of the pulp during the pulpotomy treatment.

The control of bleeding during the pulp conservative technique is essential for the success of treatment ${ }^{27}$. The presence of a clot between the pulp tissue and the capping material (Calcium hydroxide) may impair the possibility of pulp healing. Also, a heavy bleeding during pulp cutting may conduct to higher incidence of failure when compared to moderate or poor bleeding ${ }^{19}$.

The choice of calcium hydroxide powder in this study was based on its higher stimulating effect than hard-setting cements ${ }^{15}$. Also, it presents a higher $\mathrm{pH}$ when compared to hard setting $\mathrm{CH}$ cements ${ }^{27}$, providing greater antibacterial activity, and this condition could be important in inflamed pulps exposed due to caries process. In addition, there is higher $\mathrm{Ca}^{2+}$ release in paste or powder than in calcium hydroxide cements ${ }^{22}$.

It should be pointed out that one of the major limitations of this study was the small sample size. Additionally, pulpotomies were performed in different locations (anteriorposterior; mandible-maxilla) and there were differences between the individuals' characteristics. Because of this small sample size, the correlation between the success of pulpotomy treatment and the other variables, like the patients' age and gender and tooth location were not investigated.

As stated before, there was a positive association between the clinical status of the treatment and quality of the restoration. The restoration of a pulpotomized tooth should be adequately sealed to prevent contamination by bacteria. Some studies have demonstrated the influence of microorganisms on the failure of pulp capping ${ }^{18}$. The recolonization by bacteria due to microleakage could cause the necrosis of pulp that had previously healed after conservative therapy. Bacteria and their by-products may obtain access to the pulp though tunnel defects present in the dentin barrier $^{5}$. In the absence of bacteria, pulp could heal under a series of different materials ${ }^{6,23}$. Therefore, there must be an optimal seal on the interface between the tooth and the restoration ${ }^{27}$. All restorations were performed with adhesive systems and composite resins in the present study. The rationale for this choice is based on the good sealing that could be obtained with this technique ${ }^{10}$ and also due to reinforcement of the remaining dental structure.

In the present study, quality of the restorations was evaluated according to the USPHS modified system. Despite some shortcomings, this system has been extensively used to perform clinical evaluations of dental materials. Most restorations ranked as failure have received such classification due to the presence of deflective margins or failure in the sealing. These situations may facilitate the microleakage in the restoration interface, giving access to bacteria and their by-products, which could lead to failure in the pulpotomy treatment. Composite shrinkage ${ }^{10}$, high solubility of calcium hydroxide formulas, ${ }^{9}$ low adhesive bond strength in deeper dentin $^{25}$ and adhesive systems degradation ${ }^{24}$ are important factors to be considered for vital pulp therapy. These factors can generate adhesion defects where microleakage arises along time.

Barthel, et al. ${ }^{2}$ (2000) verified that there was a significantly higher success of pulp capping when the final restorations were placed immediately (up to 48 hours following capping). Also, they found a tendency for higher failure rates for temporary restorations in relation to definite restorations. In the present study, final restorations were delayed for at least 60 days after pulpotomy treatments. During this period, the teeth were temporarily restored with ZOE cement. Such material could failure in marginal sealing under thermal or masticatory stresses, providing free access to bacteria penetration. Thus, the delay in final restoration placement in the present study could contribute to the decrease in success rate of pulpotomy treatment. Moreover, as highlighted before, the operator ability may influence the quality of the preparation and restoration ${ }^{26}$. The restorations in this study were performed by undergraduate students with only one year of experience in restorative techniques. Probably, more skilled operators could produce better sealed restorations and the perspective of pulp conservative therapy could be increased.

Despite the high level of failures observed in the present study, these results do not indicate that pulpotomy in pulps exposed during caries removal should be reconsidered. In fact, some limitations of the study that could increase the failure score are discussed above. Also, it should be highlighted that pulpotomy has a relevant social and economic importance. The technique can prevent the early loss of permanent teeth, since developing and underdeveloped countries the amount of population that could afford a root canal therapy is quite limited. Even conventional root therapy could present low success rates, as demonstrated in a systematic review performed by Weiger, et al. ${ }^{30}$ (1998).

The results of this study emphasize the need for optimization of the current techniques for conservative vital pulp therapy while new strategies are not clinically available. In fact, the recent progresses in the understandings of molecular and cellular changes during tooth development and repair could allow the development of new therapies, 
which will be more biological and will probably increase the perspectives of treatment success.

Finally, longitudinal controlled clinical trials should be conducted to confirm the results of this preliminary report.

\section{REFERÊNCIAS}

1- Barnes DM, Blank LW, Gingell JC, Gilner PP. A clinical evaluation of a resin-modified. Glass ionomer restorative material. J Am Dent Assoc 1995; 126:1245-53.

2- Barthel CR, Rosenkranz B, Leuenberg A, Roulet JF. Pulp capping of carious exposures: treatment outcome after 5 and 10 years: a retrospective study. J Endod 2000; 26:525-8.

3- Caliskan MK. Pulpotomy of carious vital teeth with periapical involvement. Int Endod J 1995; 28:172-6.

4- Caliskan MK. Success of pulpotomy in the management of hyperplastic pulpitis. Int Endod J 1993; 26:142-8.

5- Cox CF, Bergenholtz G, Heys DR, Syed SA, Fitzgerald M, Heys RJ. Pulp capping of dental pulp mechanically exposed to oral microflora: a 1-2 year observation of wound healing in the monkey. J Oral Pathol $1985 ; 14: 156-68$

6- Cox CF, Hafez AA, Akimoto N, Otsuki M, Suzuki S, Tarim B. Biocompatibility of primer, adhesive and resin composite systems on non-exposed and exposed pulps of non-human primate teeth. Am J Dent 1998; 11 Spec No:S55-63.

7- Cvek M, Lundberg M. Histological appearance of pulps after exposure by a crown fracture, partial pulpotomy, and clinical diagnosis of healing. J Endod 1983; 9:8-11.

8- Demarco FF, Mota CS, Teixeira LS, Tarquinio SBC. Pulpotomy: an alternative treatment for inflamed pulp of carious tooth (literature review and case report). RPG rev pos-grad 2002; 9:87-94.

9- Driscoll CF, Woolsey GD, Reddy TG, Craig RG. Solubility of zinc oxide-eugenol and calcium hydroxide cements in simulated dentinal fluid. J Oral Rehabil 1989; 16:451-5.

10- Eick JD, Gwinnett AJ, Pashley DH, Robinson SJ. Current concepts on adhesion to dentin. Crit Rev Oral Biol Med 1997; 8:306-35.

11- Estrela C, Zina O, Borges AH. Correlação entre o diagnóstico clínico da polpa dental inflamada e o reparo após pulpotomia. ROBRAC 1996; 6:4-8

12- Fuks AB, Bielak S, Chosak A. Clinical and radiographic assessmen of direct pulp capping and pulpotomy in young permanent teeth. Pediatr Dent 1982; 4:240-4.

13- Grossman LJ, Oliet S, Del Rio EC. Endodontic Practice. Philadelphia: Lea \& Febiger; 1988.

14- Heide S, Mjor IA. Pulp reactions to experimental exposures in young permanent monkey teeth. Int Endod J 1983; 16:11-9.

15- Heys DR, Fitzgerald M, Heys RJ, Chiego DJ, Jr. Healing of primate dental pulps capped with Teflon. Oral Surg Oral Med Oral Pathol 1990; 69:227-37.

16- Holland R, de Souza V, de Mello W, Nery MJ, Bernabe PF, Otoboni Filho JA. Permeability of the hard tissue bridge formed after pulpotomy with calcium hydroxide: a histologic study. J Am Dent Assoc 1979; 99:472-5.
17- Horsted P, Sandergaard B, Thylstrup A, El Attar K, Fejerskov O. A retrospective study of direct pulp capping with calcium hydroxide compounds. Endod Dent Traumatol 1985; 1:29-34.

18- Kakehashi S, Stanley HR, Fitzgerald RJ. The Effects of Surgical Exposures of Dental Pulps in Germ-Free and Conventional Laboratory Rats. Oral Surg Oral Med Oral Pathol 1965; 20:340-9.

19- Matsuo T, Nakanishi T, Shimizu H, Ebisu S. A clinical study of direct pulp capping applied to carious-exposed pulps. J Endod 1996; 22:551-6.

20- Mejare I, Cvek M. Partial pulpotomy in young permanent teeth with deep carious lesions. Endod Dent Traumatol 1993; 9:238-42.

21- Mjor IA. Pulp-dentin biology in restorative dentistry. Part 7: The exposed pulp. Quintessence Int 2002; 33:113-35.

22- Murray PE, Lumley PJ, Smith AJ, Ross HF. The influence of sample dimensions on hydroxyl ion release from calcium hydroxide products. Endod Dent Traumatol 2000; 16:251-7.

23- Oguntebi BR, Heaven T, Clark AE, Pink FE. Quantitative assessment of dentin bridge formation following pulp-capping in miniature swine. J Endod 1995; 21:79-82.

24- Okuda M, Pereira PN, Nakajima M, Tagami J, Pashley DH. Longterm durability of resin dentin interface: nanoleakage vs. microtensile bond strength. Oper Dent 2002; 27:289-96.

25- Pashley EL, Tao L, Matthews WG, Pashley DH. Bond strengths to superficial, intermediate and deep dentin in vivo with four dentin bonding systems. Dent Mater 1993; 9:19-22.

26- Shortall AC, Harrington E, Patel HB, Lumley PJ. A pilot investigation of operator variability during intra-oral light curing. $\mathrm{Br}$ Dent J 2002; 193:276-80.

27- Stanley HR. Criteria for standardizing and increasing credibility of direct pulp capping studies. Am J Dent 1998; 11 Spec No:S17-34.

28- Teixeira LS, Demarco FF, Coppola MC, Bonow ML. Clinical and radiographic evaluation of pulpotomies performed under intrapulpal injection of anaesthetic solution. Int Endod J 2001; 34:440-6.

29- Ward J. Vital pulp therapy in cariously exposed permanent teeth and its limitations. Aust Endod J 2002; 28.29-37.

30- Weiger R, Axmann-Krcmar D, Lost C. Prognosis of conventional root canal treatment reconsidered. Endod Dent Traumatol 1998; 14:1- 